\title{
RANCANGAN TANGKI TUNDA REAKTOR TRIGA PELAT BANDUNG
}

\author{
Reinaldy Nazar, Sudjatmi Kustituantini Alfa, Ketut Kamajaya, Rian Fitriana \\ Pusat Sains dan Teknologi Nuklir Terapan-BATAN \\ Jalan Tamansari No. 71, Bandung, 40132 \\ E-mail : reinaldynazar@batan.go.id
}

Diterima: 23-02-2018

Diterima dalam bentuk revisi: 27-03-2018

Disetujui: 30-08-2018

\begin{abstract}
ABSTRAK.
RANCANGAN TANGKI TUNDA REAKTOR TRIGA PELAT BANDUNG. Mengingat elemen bakar TRIGA tidak diproduksi lagi oleh produsen aslinya General Atomic, maka perlu diusahakan suatu solusi agar reaktor TRIGA 2000 tetap dapat beroperasi. PSTNT bersama satker-satker lain di BATAN melakukan terobosan baru dengan mengusulkan konversi bahan bakar standard TRIGA ke elemen bakar tipe pelat yang saat ini sudah diproduksi di dalam negeri. Salah satu yang harus mendapatkan perhatian dalam konversi reaktor TRIGA $2000 \mathrm{ke}$ reaktor TRIGA Pelat adalah naiknya paparan radiasi Nitrogen-16 $\left({ }^{16} \mathrm{~N}\right)$ di permukaan tangki reaktor, karena mengganti moda pendinginan teras reaktor menjadi konveksi paksa. Oleh karena itu perlu dirancang sistem tunda yang ditempatkan pada sistem primer, untuk menunda aliran air pendingin dengan kandungan ${ }^{16} \mathrm{~N}$ keluar dari tangki reaktor hingga paparan radiasi ${ }^{16} \mathrm{~N}$ yang keluar dari tangki reaktor menjadi 1000 mikroSv/jam. Sistem tunda ini diantaranya dapat berupa tangki tunda. Hasil penelitian dengan menggunakan paket program Fluent dan Gambit, diketahui tangki tunda tiga buffle dapat menunda selama 50 detik aliran air pendingin keluar tangki reaktor, untuk meluruhkan ${ }^{16} \mathrm{~N}$ selama 7 kali peluruhan. Pada makalah ini disampaikan hasil kajian rancangan tangki tunda tiga buffle untuk digunakan pada sistem tunda reaktor TRIGA Pelat sebagai reaktor TRIGA 2000 Bandung yang dikonversi.
\end{abstract}

Kata kunci: Reaktor TRIGA Pelat, konversi, elemen bakar tipe pelat, ${ }^{16} \mathrm{~N}$, tangki tunda

\section{ABSTRACT.}

DELAY TANK DESIGN OF BANDUNG TRIGA PLATE REACTOR. Due to no further production of TRIGA fuel elements by the fuel manufacturer of General Atomic, it is necessary to find a solution so that the TRIGA 2000 reactor can still operate. CANST with other work units in NNEA make a new breakthrough by proposing the conversion of standard TRIGA fuel to the fuel element of plate type which currently has been produced domestically. One of the concerns in the TRIGA 2000 reactor conversion activity is the rising exposure of ${ }^{16} \mathrm{~N}$ radiation in the surface of the reactor tank, since replacing the reactor core cooling modes into forced convection. Therefore it is necessary to design a delay system that is placed on the primary system, to delay the flow of cooling water with ${ }^{16} \mathrm{~N}$ content coming out of the reactor tank until exposure to ${ }^{16} \mathrm{~N}$ radiation coming out of the reactor tank to $1000 \mathrm{microSv} / \mathrm{hour}$. This delay system can be in the form of a delay tank. The results of the study using the Fluent and Gambit program package, it is known that the three bufle delay tank can delay for 50 seconds the flow of cooling water out of the reactor tank to shed ${ }^{16} \mathrm{~N}$ for 7 times. In this paper the results of the study of the delay tank design which has three buffles to be used on the delay system of the TRIGA Plate reactor as the Bandung TRIGA 2000 reactor being converted.

Keywords: TRIGA Plate reactor, conversion, plate type fuel element, ${ }^{16} \mathrm{~N}$, delay tank 



\section{PENDAHULUAN}

Reaktor riset dunia umumnya digunakan untuk keperluan pelaksanaan pelatihan, penelitian dan pengembangan, produksi radioisotop, analisis aktivasi neutron, uji material, permintaan dari industri, lembaga litbang, BUMN serta universitas. Oleh karena itu reaktor riset memberikan kontribusi besar terhadap perkembangan industri, energi, kesehatan dan lingkungan, terutama aplikasi radioisotop dalam bidang tersebut.

Dalam perjalanan waktu General Atomic (GA) sebagai produsen elemen bakar untuk reaktor TRIGA 2000 Bandung berhenti memproduksi elemen bakar (1-2), dengan demikian kelanjutan operasi reaktor jenis TRIGA akan mengalami penghentian sehubungan dengan tidak tersedianya pasokan elemen bakar.

Dalam menghadapi kondisi ini Pusat Sains dan Teknologi Nuklir Terapan (PSTNT) bersama dengan satker-satker lain di Badan Tenaga Nuklir Nasional (BATAN) berinisiatif melakukan langkah terobosan baru melalui penelitian-penelitian terhadap konversi elemen bakar standard TRIGA berbentuk batangan ke elemen bakar tipe pelat (3-7).

Solusi ini diambil dengan tujuan untuk mengurangi ketergantungan membeli elemen bakar import, karena BATAN dalam hal ini PT. Industri Nuklir Indonesia (INUKI) sudah mampu membuat dan merakit elemen bakar tipe pelat (8).

Reaktor TRIGA Pelat sebagai reaktor hasil konversi dari reaktor TRIGA berbahan bakar bentuk batangan ke elemen bakar tipe pelat harus mendapat perhatian, diantaranya naiknya paparan radiasi ${ }^{16} \mathrm{~N}$ di permukaan tangki reaktor, karena mengganti moda pendinginan teras reaktor menjadi konveksi paksa $(9,10)$. Oleh karena itu perlu dirancang sistem tunda yang ditempatkan pada sistem primer, untuk menunda aliran ${ }^{16} \mathrm{~N}$ keluar dari tangki reaktor hingga paparan radiasi ${ }^{16} \mathrm{~N}$ yang keluar dari tangki reaktor turun.

Pada prinsipnya tangki tunda adalah adalah wadah yang digunakan untuk menyimpan air pendingin primer yang berasal dari teras reaktor dalam jumlah tertentu dan selama waktu tertentu, hingga konsentrasi ${ }^{16} \mathrm{~N}$ di dalam air pendingin primer tersebut mencapai batas ambang keselamatan. Pada tangki tunda fenomena rongga udara yang terjebak dapat terjadi ketika reaktor beroperasi, yang dapat mempengaruhi kenaikan tekanan tangki dan kavitasi pada pompa. Hal ini dapat diatasi dengan menempatkan katup ventilasi pada tangki untuk mengeluarkan udara tersebut.

Sistem tunda dapat berupa pipa tunda dan tangki tunda. Pipa tunda dimaksudkan untuk memperpanjang lintasan aliran ${ }^{16} \mathrm{~N}$ mencapai permukaan tangki, dengan tujuan memperpanjang waktu tempuh ${ }^{16} \mathrm{~N}$ mencapai permukaan tangki. Sistem pipa tunda membutuhkan pipa yang sangat panjang, semakin panjang pipa yang digunakan akan semakin banyak ruang yang diperlukan untuk menempatinya, sehingga hal inipun akan memiliki potensi kendala.

Pada makalah ini diinformasikan hasil kajian menggunakan paket program komputer Fluent dan Gambit terhadap rancangan tangki tunda yang dapat digunakan pada reaktor TRIGA Pelat, sebagai reaktor konversi dari berbahan bakar berbentuk batangan ke elemen bakar tipe pelat. 


\section{TEORI}

Berdasarkan hasil perhitungan yang telah dilakukan dengan menggunakan program computer CFD, diketahui bahwa reaktor TRIGA Pelat jika dioperasikan pada daya $2000 \mathrm{~kW}$ dengan laju alir pendingin 50 $\mathrm{kg} / \mathrm{s}$ diketahui temperatur permukaan pelat elemen bakar $121,19{ }^{\circ} \mathrm{C}$. Temperatur ini sudah melebihi temperatur saturasi $112,4{ }^{\circ} \mathrm{C}$. Hal ini menunjukkan bahwa di dalam teras sudah terjadi pendidihan inti. Dengan demikian dapat dikatakan bahwa pengoperasian reaktor TRIGA Pelat tidak dapat dilakukan dengan moda pendinginan konveksi alamiah tetapi dengan moda konveksi paksa.

Jika reaktor dioperasikan pada daya 2000 kW dengan moda pendinginan konveksi paksa, dimana laju pendingin masuk ke teras $70 \mathrm{~kg} / \mathrm{s}$ maka diperoleh temperatur permukaan pelat elemen bakar $109,98{ }^{\circ} \mathrm{C}$, dan temperatur ini adalah berada di bawah temperatur saturasi $112,4^{\circ} \mathrm{C}$.

Penggantian moda pengambilan panas di teras reaktor oleh pendingin primer dari proses konveksi alamiah menjadi konveksi paksa menyebabkan perlu dilakukan pengelolaan konsentrasi Nitrogen-16 $\left({ }^{16} \mathrm{~N}\right)$ yang keluar dari teras dan sebelum keluar dari tangki reaktor. Dengan demikian pada sistem pendingin primer reaktor TRIGA Pelat dibutuhkan sistem tunda yang berfungsi menunda air pendingin primer dengan kandungan ${ }^{16} \mathrm{~N}$ keluar dari tangki reaktor, hingga kandungan konsentrasi ${ }^{16} \mathrm{~N}$ turun mencapai batas ambang keselamatan 1000 mikroSv/jam.

\section{TATA KERJA}

Perancangan model sistem tunda yang dapat digunakan pada reaktor TRIGA Pelat dilakukan dengan metoda simulasi menggunakan bantuan paket program Fluent dan Gambit.

Simulasi model tangki tunda dilakukan dengan membuat gambar 3D (3 dimensi) menggunakan program Gambit terhadap seluruh sistem tangki tunda beserta komponen yang terdapat di dalamnya. Sedangkan analisis yang dilakukan hanya untuk komponen laju aliran saja, karena pada sistem tangki tunda ini tidak terjadi proses perpindahan panas.

Dalam melakukan kajian model tangki tunda perlu ditetapkan beberapa kondisi batas yang menjadi dasar perhitungan dalam mendesain model tangki tunda, yaitu :

1. Meminimalkan penggantian komponen reaktor yang sudah ada, sehingga bentuk kegiatan ini dapat disebut melakukan modifikasi reaktor TRIGA 2000 menjadi reaktor TRIGA Pelat

2. Laju alir air pendingin primer yang masuk ke tangki tunda adalah $70 \mathrm{~kg} / \mathrm{s}$ yang diperoleh dengan mengoperasi dua pompa primer yang sudah ada dan tersusun paralel.

3. Hasil perhitungan neutronik, diketahui waktu yang dibutuhkan agar konsentrasi ${ }^{16} \mathrm{~N}$ berada di bawah ambang batas keselamatan adalah 50 detik atau setelah terjadi 7 kali peluruhan dengan waktu paruh ${ }^{16} \mathrm{~N}$ adalah 7,1 detik $(9,10)$.

Pada prinsipnya sistem tunda pada reaktor TRIGA Pelat adalah wadah yang 
digunakan untuk menyimpan air pendingin primer yang berasal dari teras dalam jumlah tertentu selama 50 detik, hingga konsentrasi ${ }^{16} \mathrm{~N}$ di dalam air pendingin primer tersebut mencapai batas ambang keselamatan.

Perhitungan sistem tunda berbentuk tangki tunda adalah sebagai berikut.

$$
\text { volume }=\vartheta=\frac{(m . t)}{\rho}
$$

Berdasarkan persamaan (1) diketahui volume air pendingin yang disimpan selama 50 detik adalah $3,5 \mathrm{~m}^{3}$. Jika digunakan alokasi cadangan volume $10 \%$, maka volume total tangki yang dibutuhkan adalah $3,85 \mathrm{~m}^{3}$. Berdasarkan ruang yang tersedia untuk penempatan tangki tunda, maka spesifikasi tangki tunda dengan volume $3,85 \mathrm{~m}^{3}$ adalah tangki dengan diameter $=1,4 \mathrm{~m}$, dan tinggi 2,50 m dimana tangki ini membutuhkan ruangan hanya seluas $1,54 \mathrm{~m}^{2}$ untuk menempatkannya.

Dalam rancangan ini dianalisis beberapa model tangki tunda (10-12). Pada tangki tunda yang dirancang, buffle plate ditempatkan dengan jumlah yang bervariasi. Buffle plate adalah alat yang digunakan untuk menahan atau mencegah aliran air pendingin primer secara acak di dalam tangki tunda, dan mengatur lamanya setiap air pendingin primer berada di dalam tangki tunda. Sehingga terjadi sistem pengaturan keluar masuk air pendingin di dalam tangki tunda, dimana pendingin yang pertama keluar dari tangki tunda adalah pendingin yang pertama masuk ke dalam tangki tunda. Sistem buffle plate ini sama halnya dengan sistem buffle plate pada tangki tunda yang digunakan di RSG-GAS dan reaktor riset di Korea (10). Pada laporan ini dianalisis beberapa rancangan tangki tunda yang memiliki 1 buffle plate, 2 buffle plate, dan 3 buffle plate. Buffle plate terbuat dari Al dengan ketebalan $0,6 \mathrm{~cm}$. Buffle plate memiliki lubang-lubang berbentuk persegi dengan ukuran $6 \mathrm{~cm} \times 6 \mathrm{~cm}$ dan jarak antar lubang adalah $6 \mathrm{~cm}$. Untuk mengakomodasi ruangan udara yang terjebak di dalam aliran sehingga tidak merusak pompa akibat kavitasi, maka perlu dialokasikan ruangan tingginya 10 $\mathrm{cm}$. Dengan demikian tinggi total tangki tunda menjadi $260 \mathrm{~cm}$. Tangki terbuat dari pelat Al dengan ketebalan 0,6 cm. Untuk mengeluarkan udara yang terjebak dari tangki tunda, ditempatkan pipa ventilasi dan katupnya pada tutup tangki tunda dengan tinggi $20 \mathrm{~cm}$, dan diameter $5 \mathrm{~cm}$. Saluran air pendingin primer masuk dan keluar tangki tunda melalui dua buah lubang yang dibuat dengan diameter masing-masing adalah 15 $\mathrm{cm}$. Hal ini disesuaikan dengan diameter pipa pendingin primer yang digunakan.

Dengan menggunakan paket program komputer Fluent dan Gambit telah dimodelkan beberapa tangki tunda reaktor TRIGA Pelat, masing-masing memiliki 1 buffle plate, 2 buffle plate, dan 3 buffle plate.

\section{HASIL DAN PEMBAHASAN}

\section{Model Tangki Tunda Satu Buffle Plate}

Gambar 1 adalah visual model geometri 3D tangki tunda dengan 1 buffle plate yang dibentuk menggunakan program Gambit dan dilengkapi dengan dimensi tangki tunda yang digunakannya. Gambar 1b adalah pandangan tampak atas buffle plate

Gambar 2 adalah visual bentuk grid yang dibangun pada geometri model tangki tunda 1 buffle plate menggunakan program Gambit. 



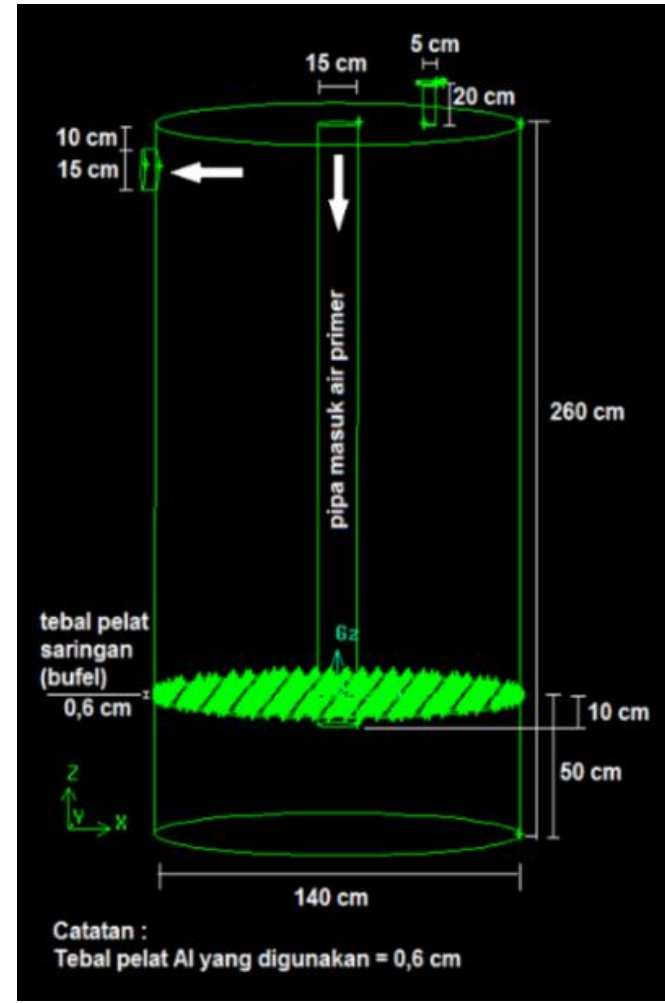

(a)

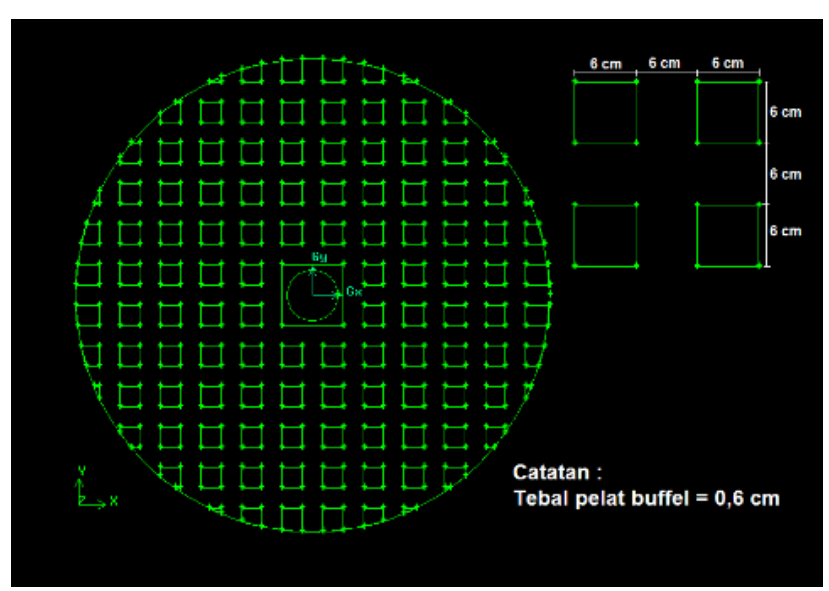

(b)

Gambar 1. (a) Model 3D tangki tunda, dan (b) tampak atas buffle plate
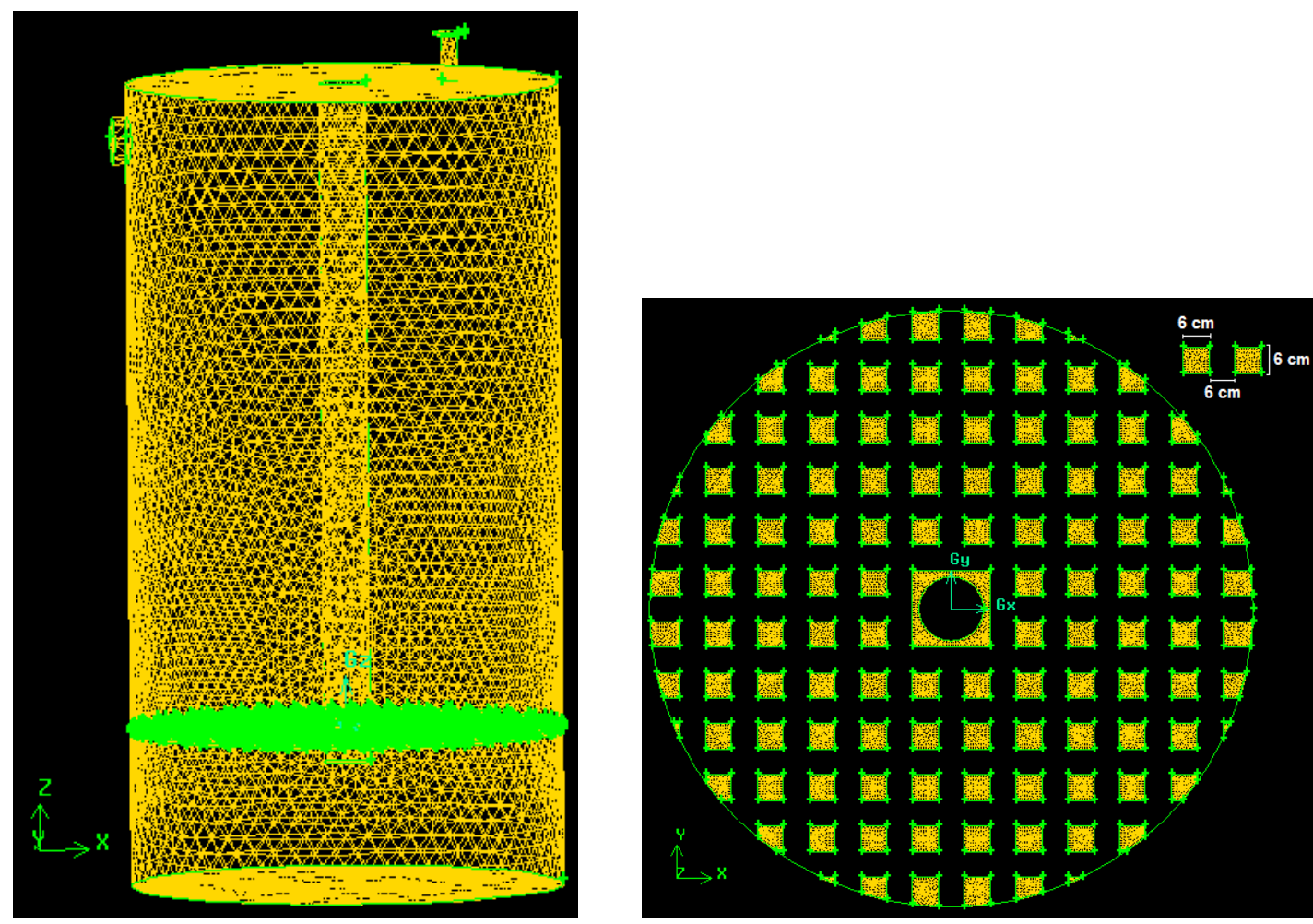

Gambar 2. Grid geometri 3D tangki tunda 1 buffle plate dan grid buffle plate 


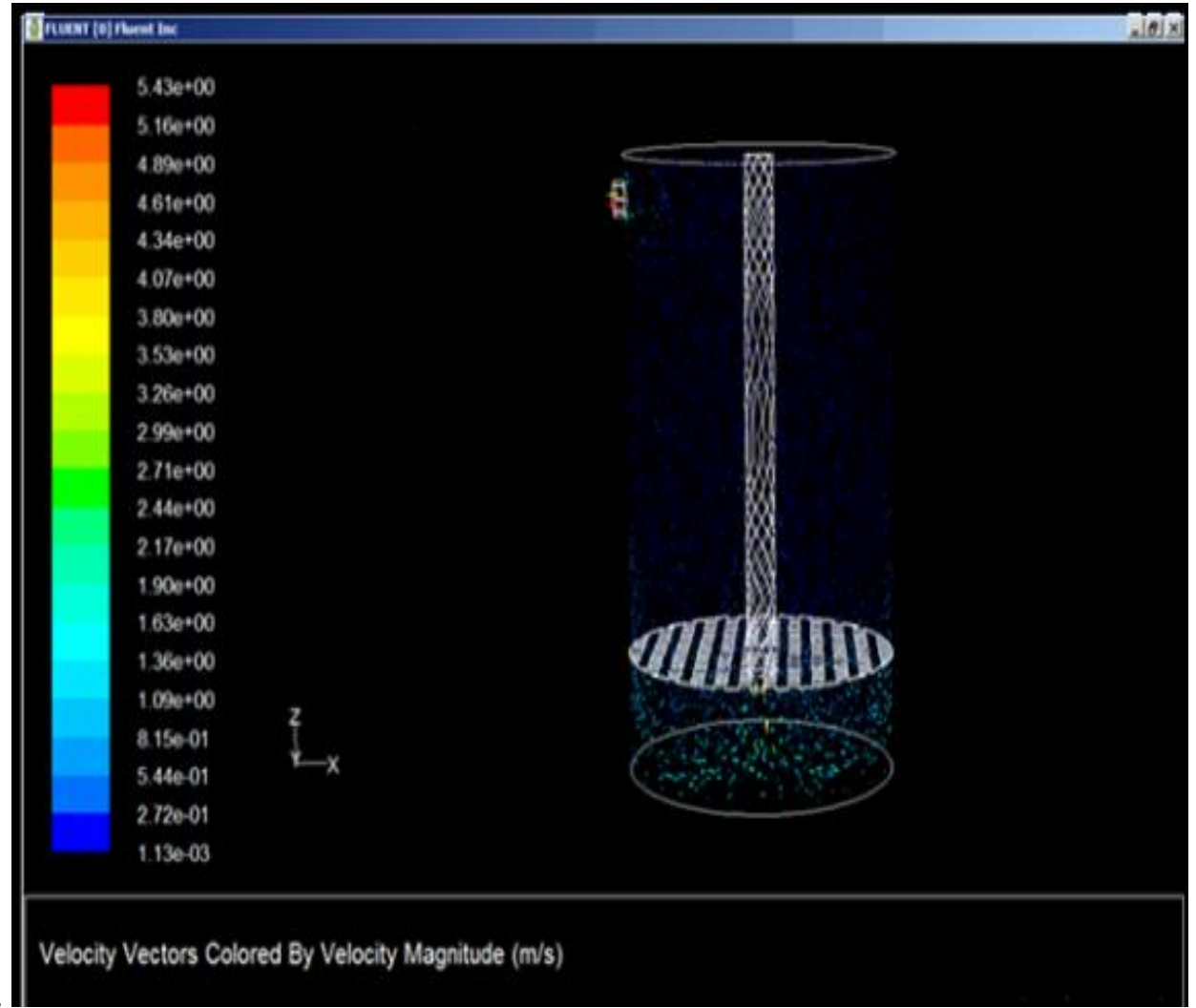

Gambar 3. Vektor kecepatan pendingin primer di dalam tangki tunda

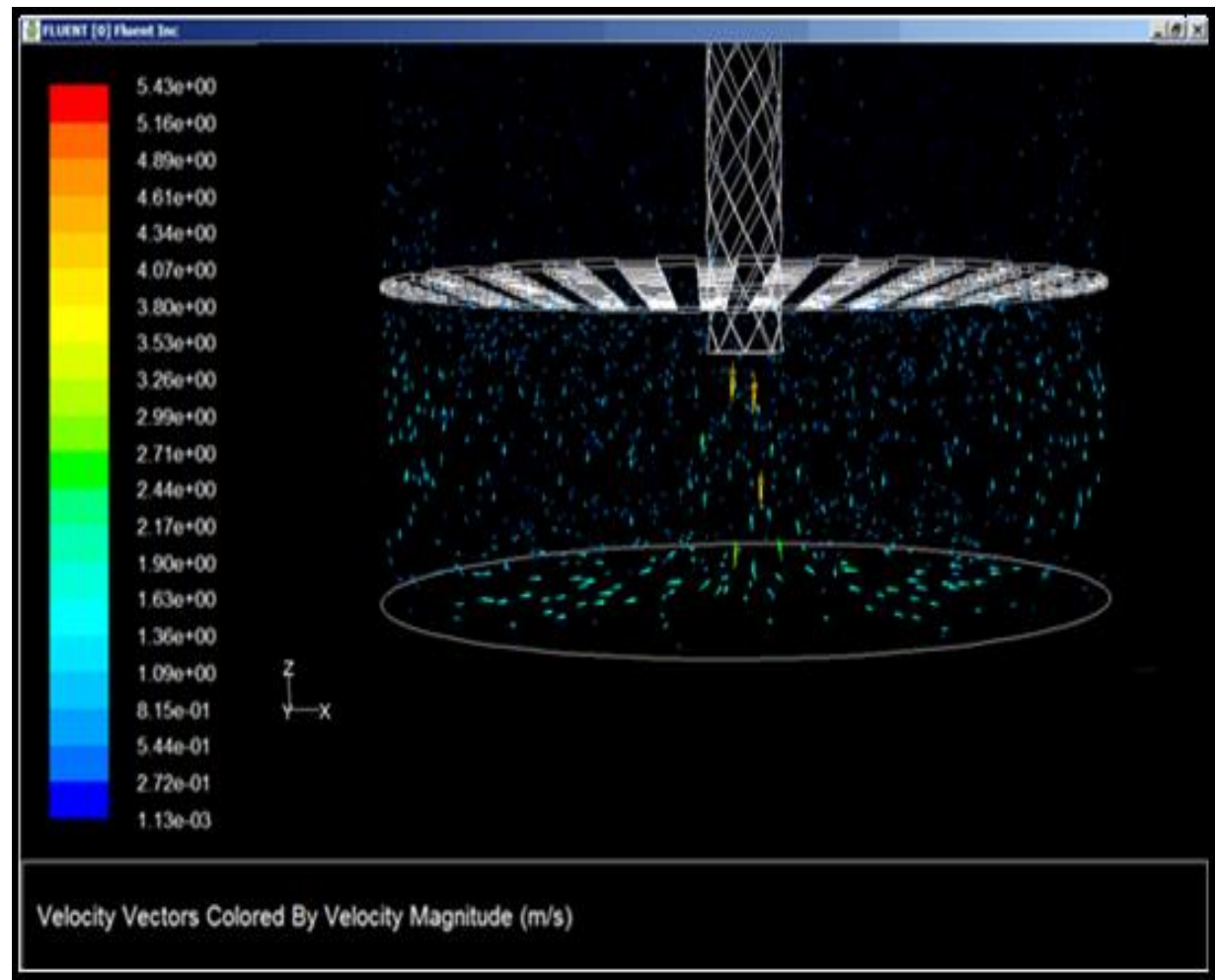

Gambar 4. Vektor kecepatan pendingin primer di bawah buffle plate 
Gambar 3 dan 4 menunjukkan visual vektor-vektor kecepatan aliran pendingin di dalam tangki tunda 1 buffle plate hasil perhitungan menggunakan program Fluent. Terlihat distribusi kecepatan aliran air primer di dalam tangki tunda tidak homogen dari buffle plate hingga mencapai pipa keluaran. Sehingga tidak dapat diharapkan pendingin yang pertama keluar dari tangki tunda adalah pendingin yang pertama masuk ke tangki tunda. Akibatnya terdapat air pendingin dengan kandungan ${ }^{16} \mathrm{~N}$ yang masih tinggi atau belum mengalami 7 kali peluruhan sudah keluar dari tangki tunda.

\section{Model Tangki Tunda Dua Buffle Plate}

Gambar 5 adalah visual model geometri 3D tangki tunda dengan 2 buffle plate yang dibentuk menggunakan program Gambit dan dimensinya. Gambar 6 adalah visual bentuk grid yang dibangun pada geometri model tangki tunda 2 buffle plate menggunakan program Gambit

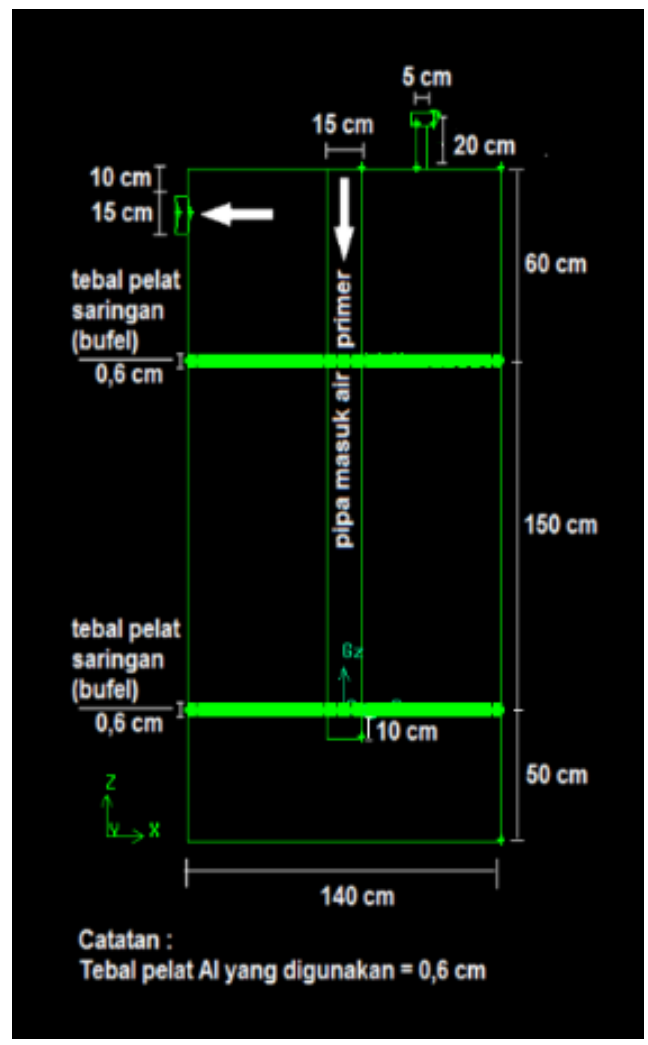

(b)

Gambar 5. (a) Model 3D tangki tunda 2 buffle plate, (b) penampang tegak tangki tunda, 

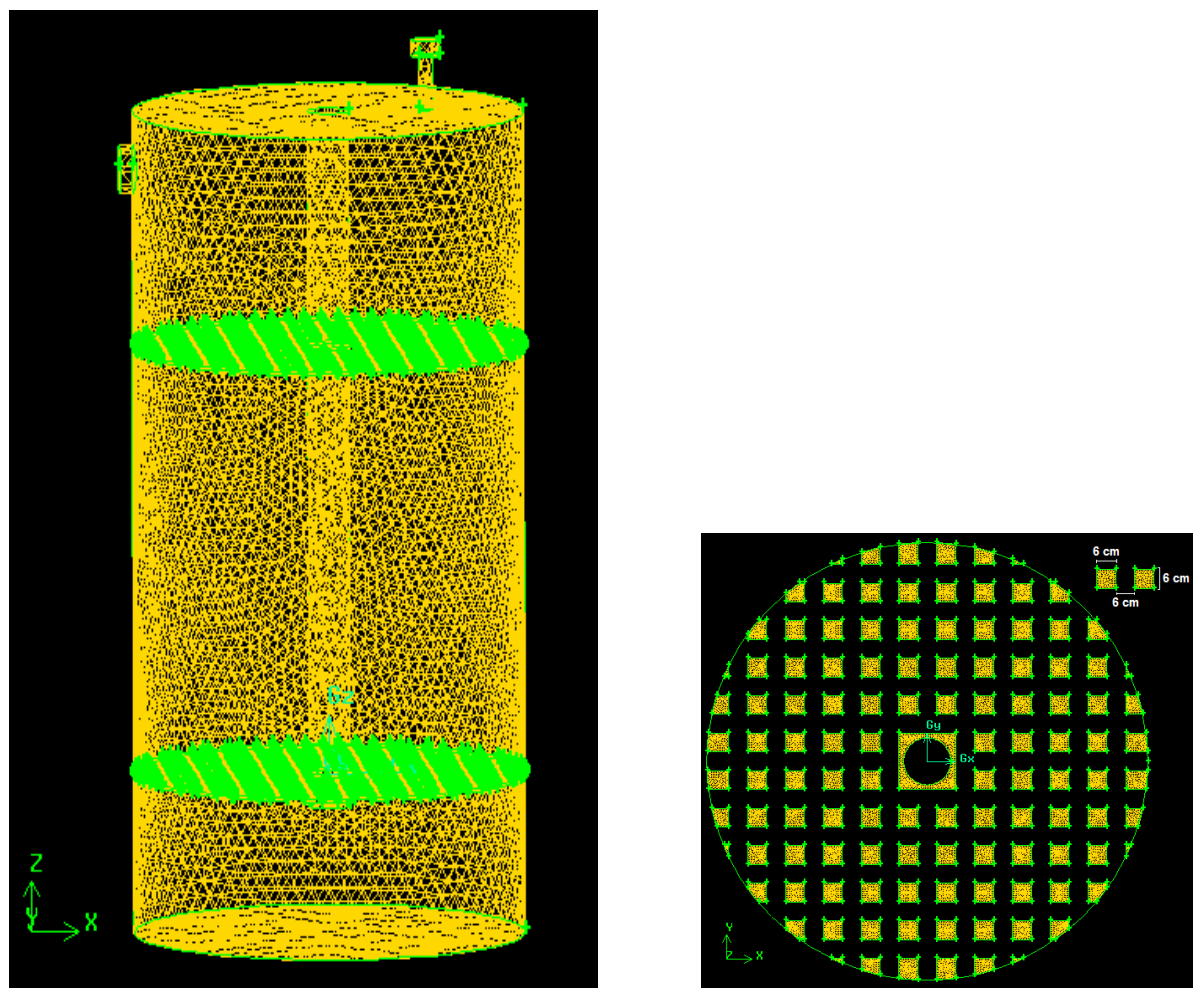

Gambar 6. Grid geometri 3D tangki tunda 2 buffle plate

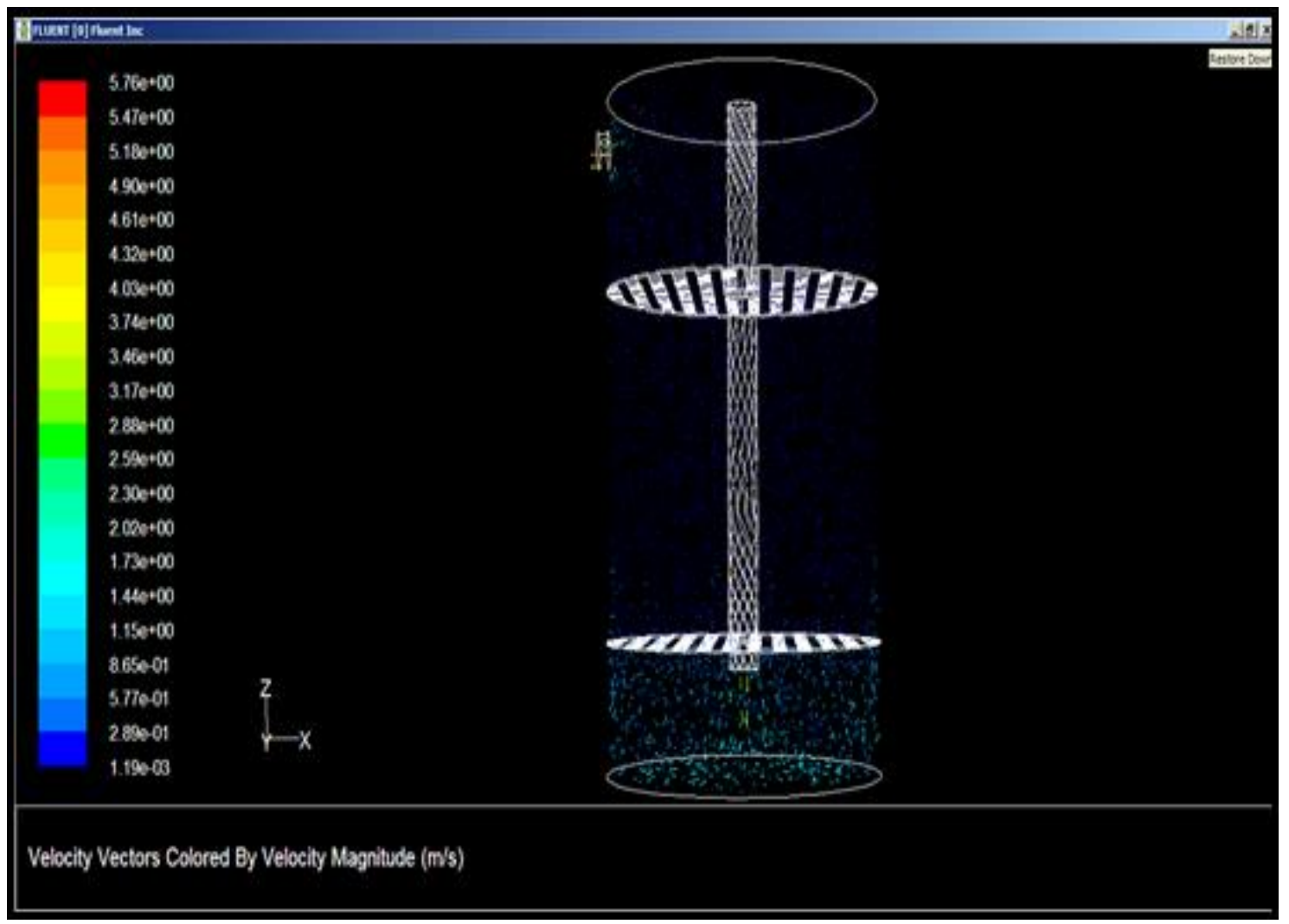

Gambar 7. Vektor kecepatan pendingin primer di dalam tangki tunda 


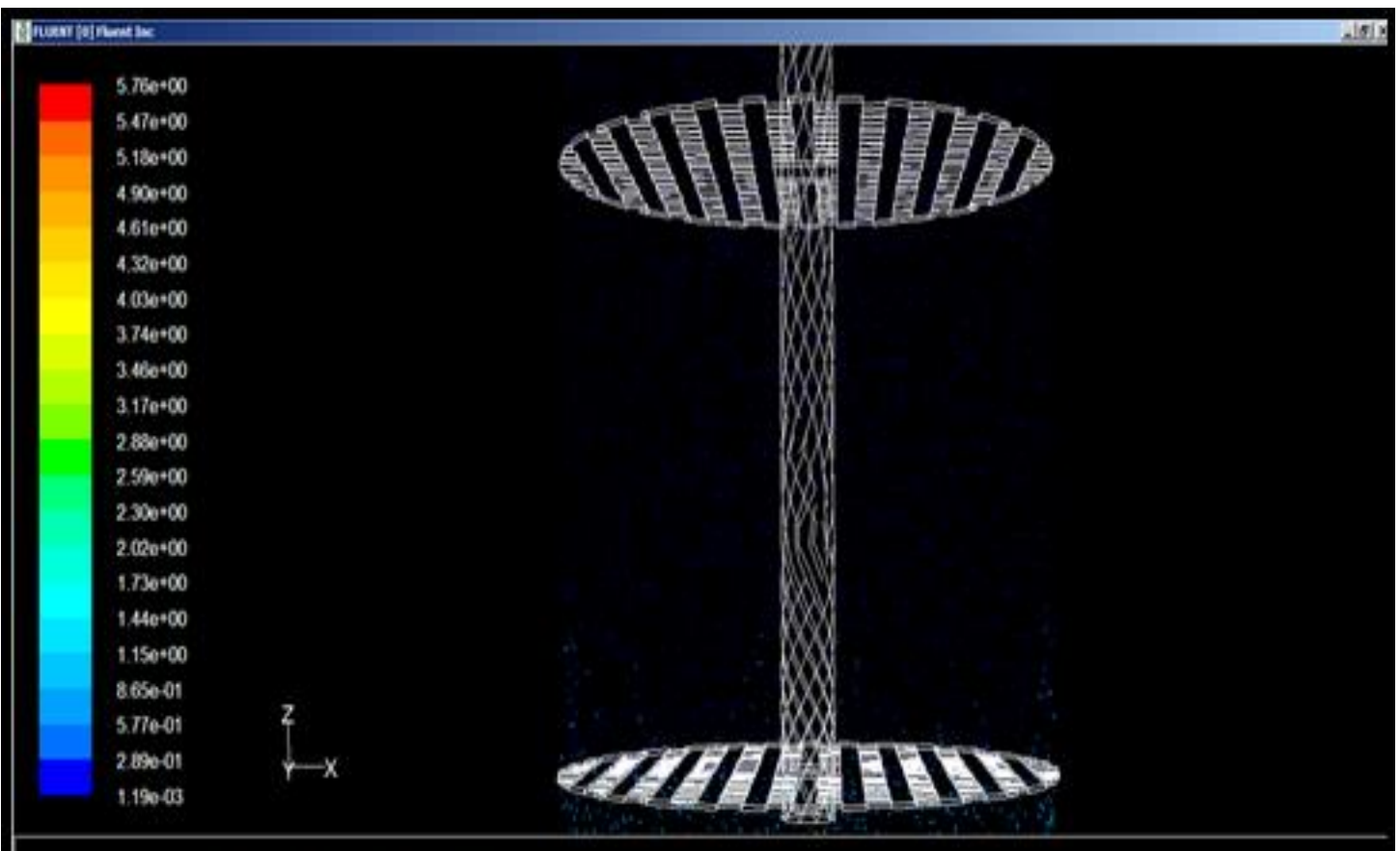

Gambar 8. Vektor kecepatan pendingin primer di sekitar buffle plate

Gambar 7 dan 8 menunjukkan visual vektor-vektor kecepatan aliran di dalam tangki tunda 2 buffle plate. Terlihat distribusi kecepatan aliran air pendingin primer di dalam tangki tunda tidak homogen dari buffle plate bawah hingga mencapai pipa keluaran. Sehingga tidak dapat diharapkan pendingin yang pertama keluar dari tangki tunda adalah pendingin yang pertama masuk ke tangki tunda. Akibatnya terdapat air pendingin dengan kandungan ${ }^{16} \mathrm{~N}$ yang masih tinggi atau belum mengalami 7 kali peluruhan sudah keluar dari tangki tunda.

\section{Model Tangki Tunda Tiga Buffle Plate}

Gambar 9 adalah visual model geometri 3D tangki tunda 3 buffle plate yang dibentuk menggunakan program Gambit dan dimensinya. Gambar 10 adalah visual bentuk grid yang dibangun pada geometri model tangki tunda 3 buffle plate menggunakan program Gambit 


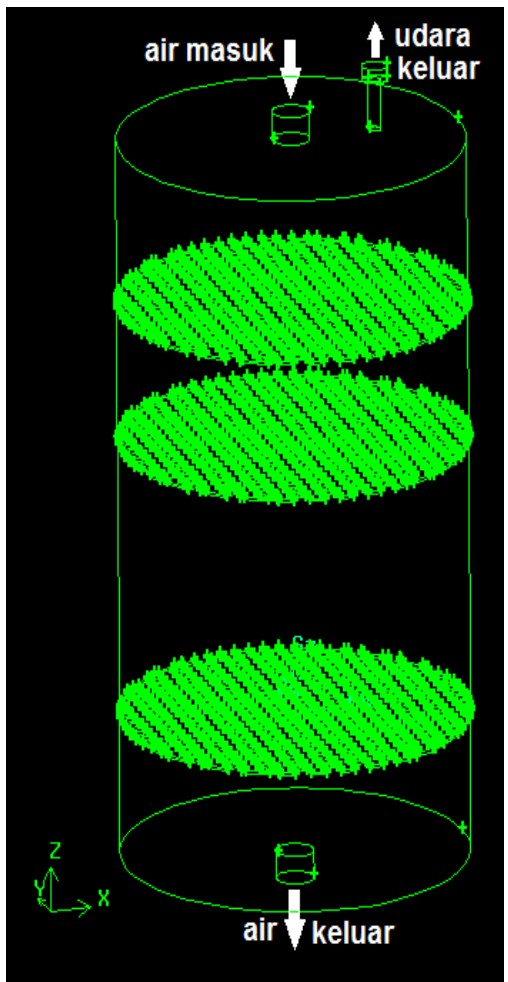

(a)

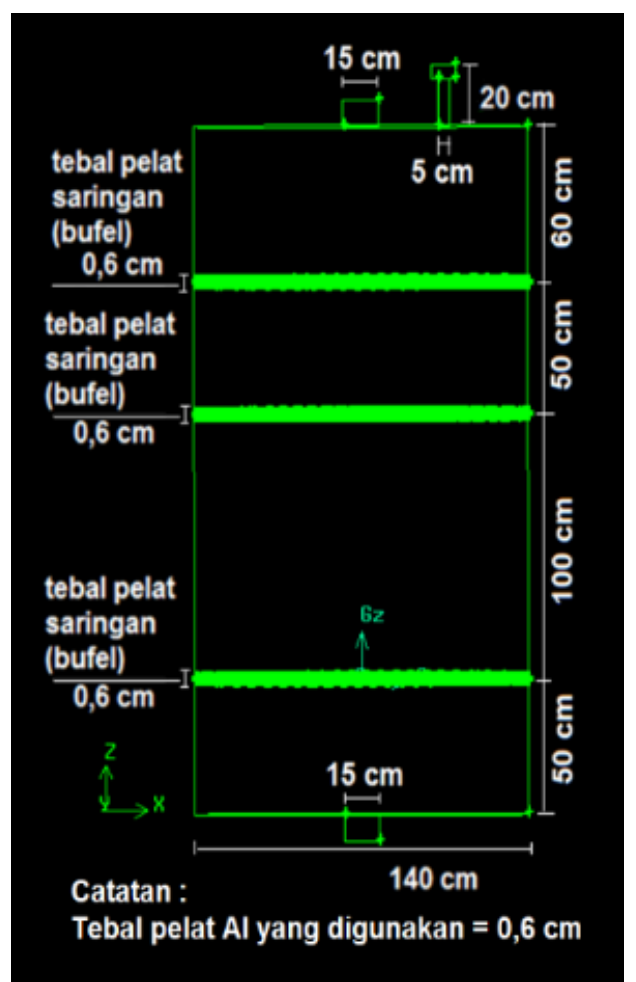

(b)

Gambar 9. (a) Model 3D tangki tunda 3 buffle plate, (b) penampang tegak tangki tunda,
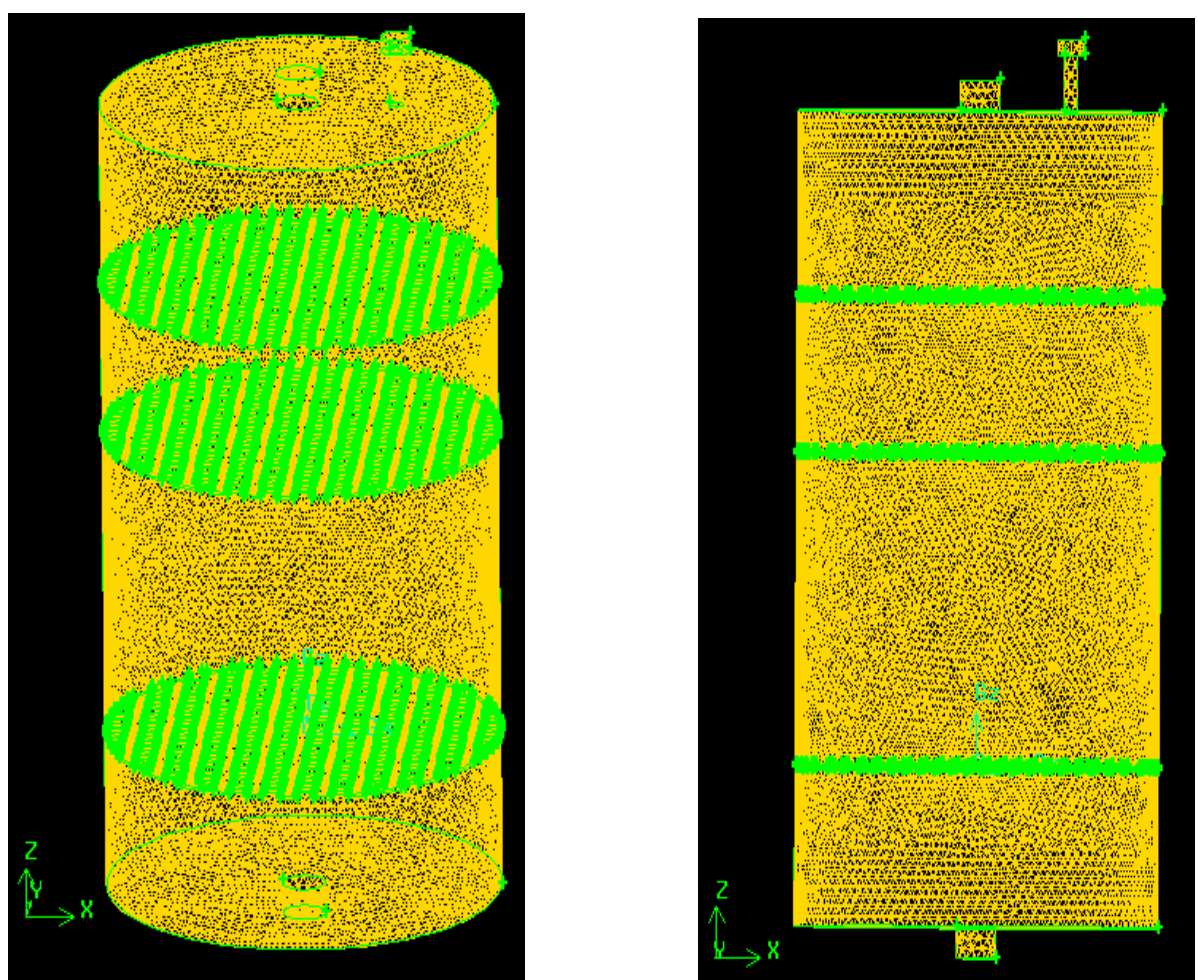

Gambar 10. Grid geometri 3D tangki tunda 3 buffle plate 


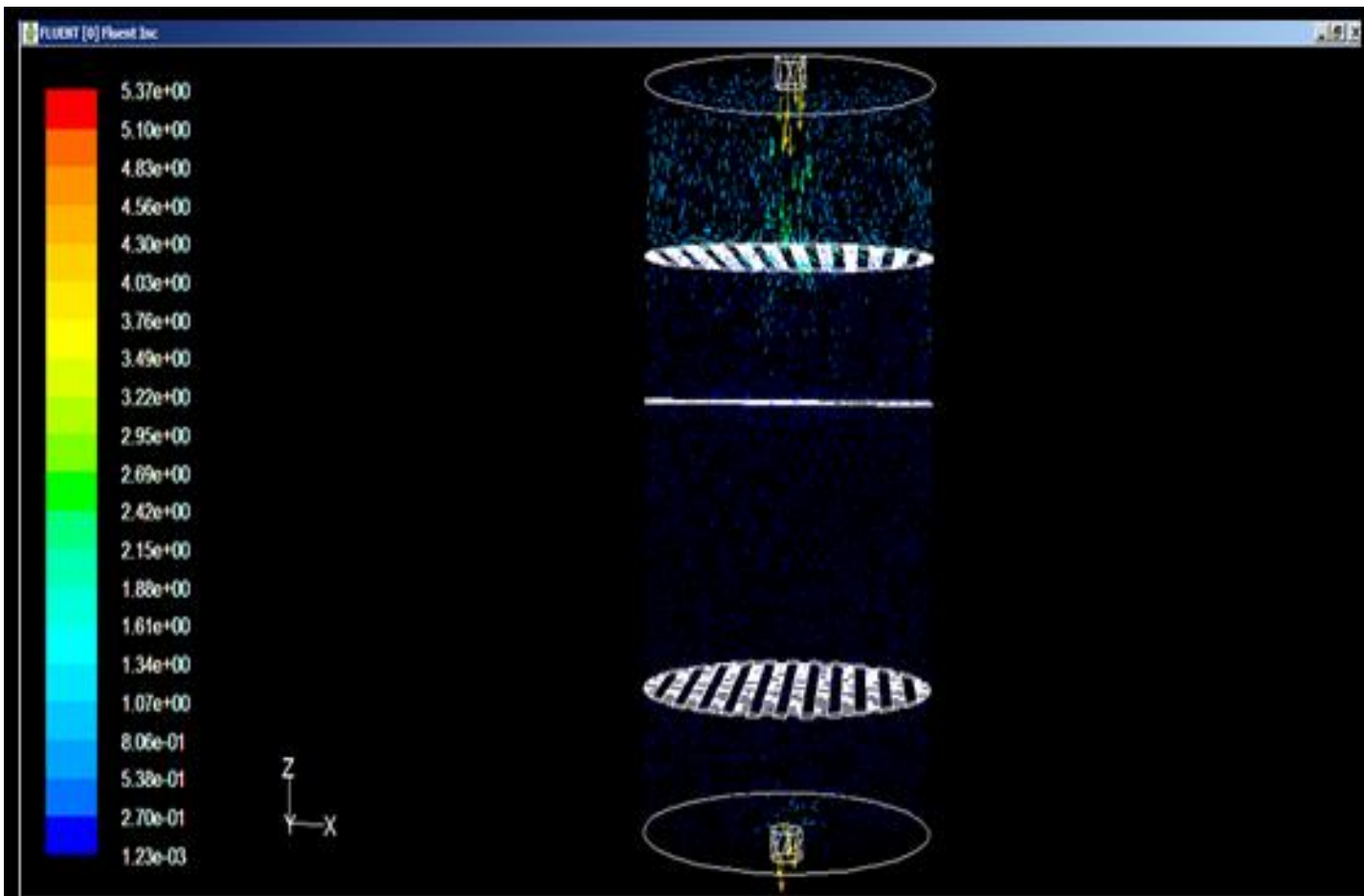

Velocily Vectors Colored By Velocity Magritude (m/s)

Gambar 11. Vektor kecepatan pendingin primer

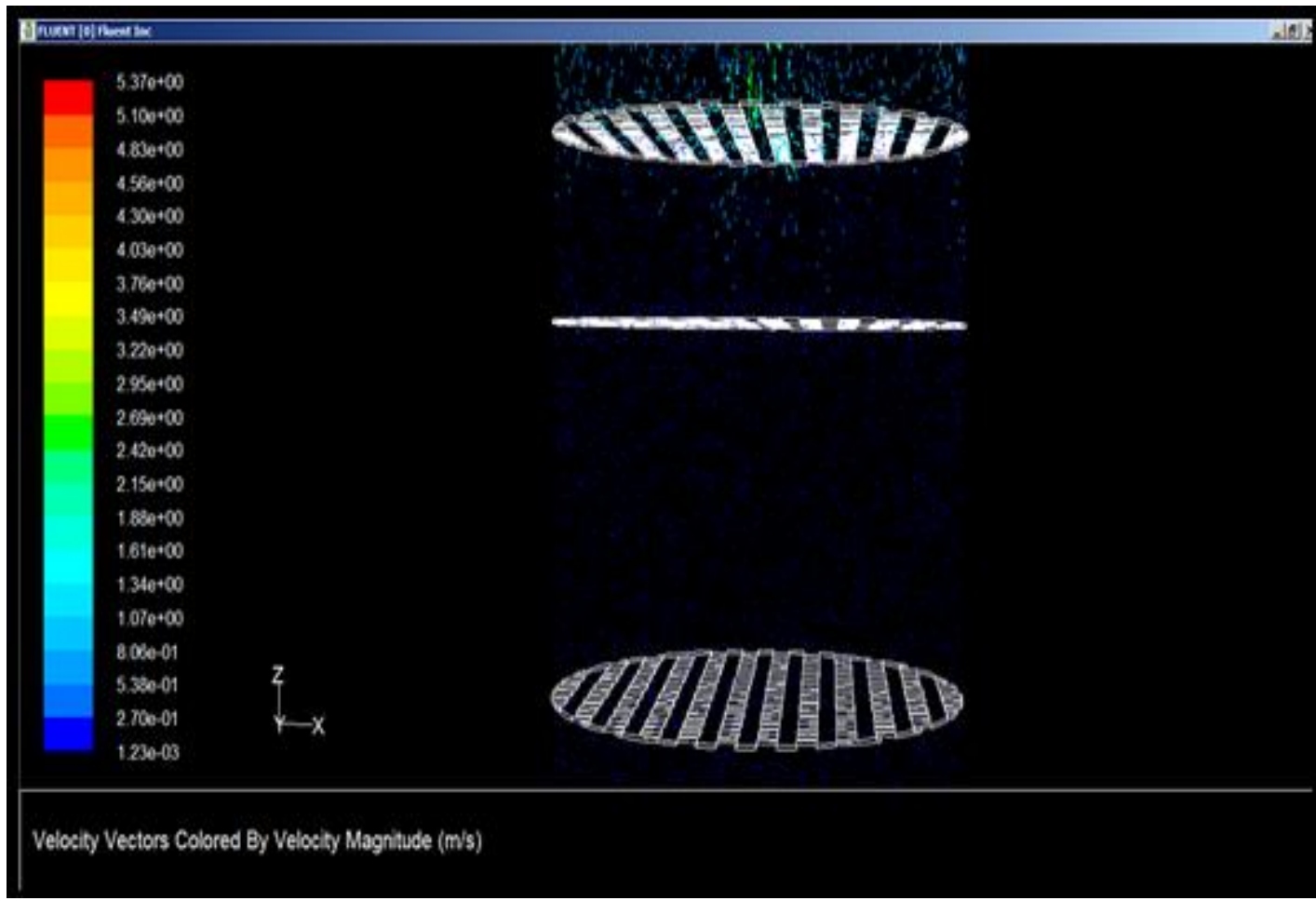

Gambar 12. Vektor kecepatan pendingin primer di sekitar buffle plate 


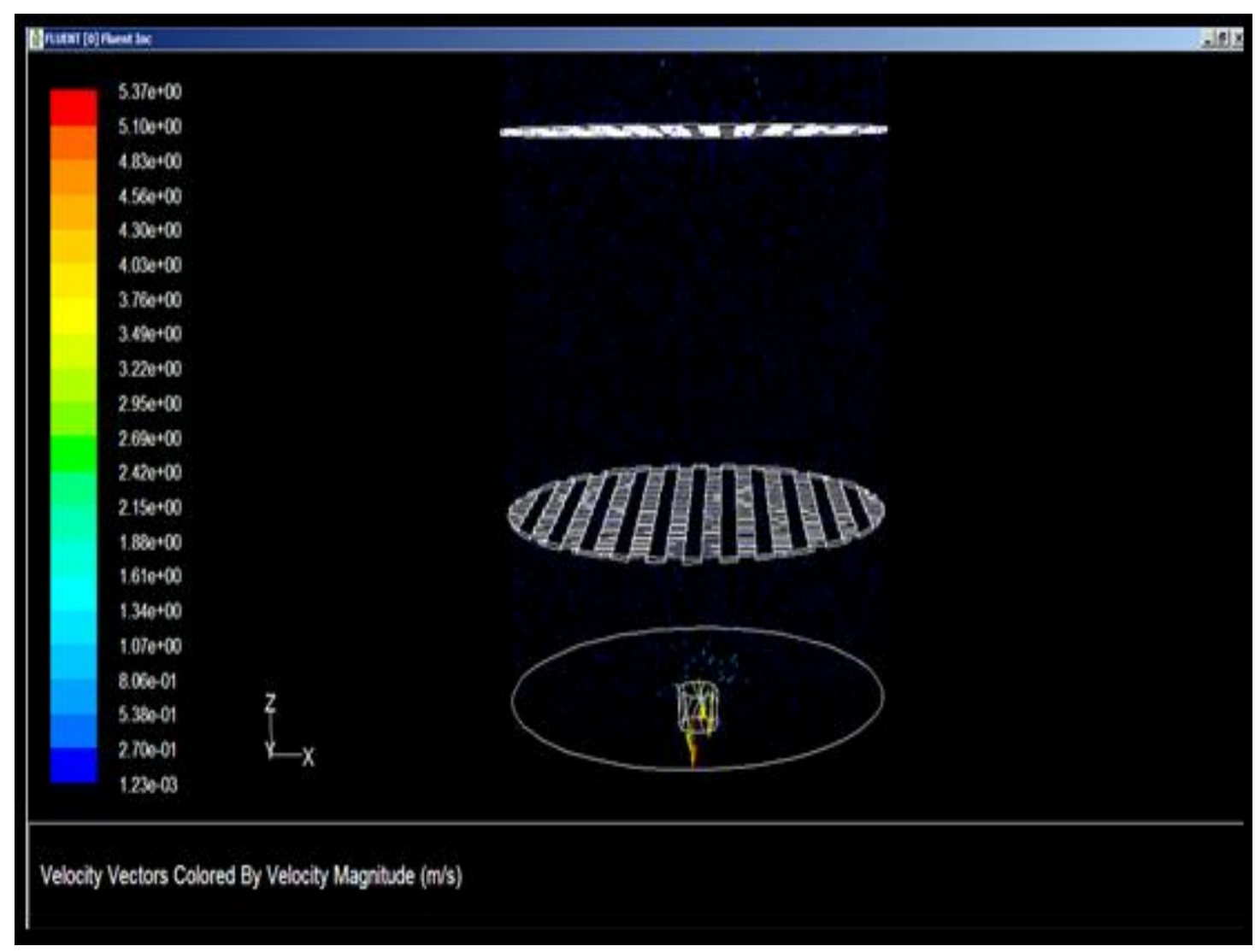

Gambar 13. Vektor kecepatan pendingin primer di sekitar dasar tangki tunda

Gambar 11, 12 dan 13 menunjukkan visual vektor-vektor kecepatan aliran di dalam tangki tunda 3 buffle plate. Terlihat distribusi kecepatan aliran air pendingin primer di dalam tangki tunda homogen (merata) di setiap tempat antara buffle plate tengah hingga ke pipa keluaran. Sehingga dapat dinyatakan pendingin yang pertama keluar dari tangki tunda adalah pendingin yang pertama masuk ke tangki tunda. Dengan demikian pada model tangki tunda 3 buffle plate ini tentunya seluruh air primer dengan kandungan ${ }^{16} \mathrm{~N}$ sudah mengalami peluruhan sebanyak 7 kali atau semua air pendingin primer telah berada di dalam tangki tunda selama 50 detik sebelum keluar dari pipa keluaran.

\section{Model Tangki Tunda Optimal}

Berdasarkan posisi penempatan pipa masukan dan pipa keluaran pada tangki tunda diketahui bahwa, model tangki tunda 3 buffle plate menurut Gambar 14 lebih optimal. Posisi pipa masukan dan pipa keluaran pada model tangki tunda 3 buffle plate lebih meringankan kerja pompa, dengan pressure drop lebih rendah dari dua model yang lainnya, karena dengan posisi pipa masukan dan pipa keluaran tersebut terjadi aliran jatuh bebas dari pipa masukan. 


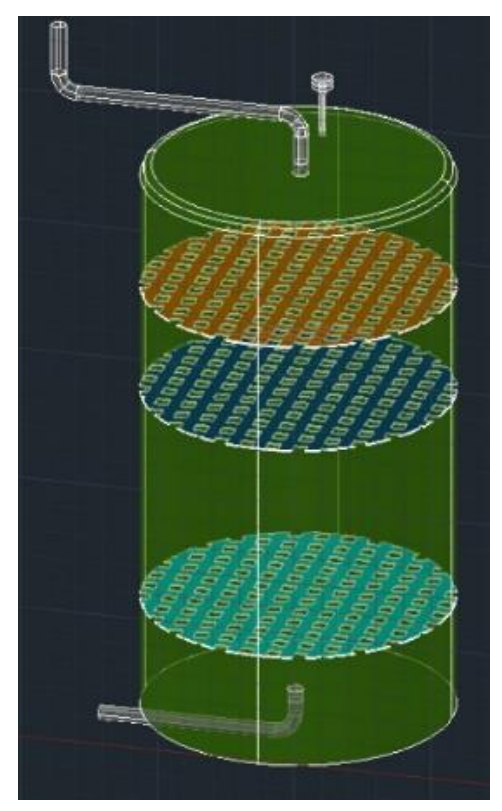

Gambar 14. Visualisasi riil tangki tunda dengan 3 buffle plate yang diusulkan

\section{Proses Konstruksi Dan Perawatan}

Proses konstruksi dan perawatan tangki tunda yang dirancang sangat mudah dilakukan. Untuk konstruksi tangki tunda ini dibutuhkan tangki Al tebal 0,6 cm yang bagian alasnya dilas, sedangkan tutup atasnya tidak dilas untuk memudahkan perawatan. Diameter tangki 1,40 $\mathrm{m}$ dan tingginya 2,60 m. Bagian dasar tangki memiliki lubang dengan diameter $0,15 \mathrm{~m}$, atau ditempatkan pipa dengan diameter $0,15 \mathrm{~m}$ yang menembus ketebalan dasar tangki. Lubang ini berguna untuk saluran keluar air pendingin primer dari tangki tunda menuju ke pompa primer.

Bagian tutup tangki tidak dilas untuk memudahkan perawatan. Untuk saluran masuk air pendingin primer dari teras reaktor ke tangki tunda, pada tutup tangki ditempatkan pipa dengan diameter $0,15 \mathrm{~m}$ yang menembus tutup tangki hingga masuk $0,10 \mathrm{~m}$ ke dalam tangki. Hal ini dimaksudkan untuk mengakomodasi ruangan udara yang terjebak terbawa aliran, untuk kemudian dibuang melalui pipa ventilasi dengan diameter 0,05 $\mathrm{m}$ yang ditempatkan pada tutup tangki.

Tiga buffle plate yang berguna untuk penyearah atau pengatur arus aliran di dalam tangki tunda, masing-masing ditempatkan pada ketinggian $0,50 \mathrm{~m}, 1,50 \mathrm{~m}$, dan 2,00 m dari dasar tangki. Untuk mempermudah proses perawatannya setiap buffle plate hanya ditopang (tidak dilas) dengan 4 buah penyangga yang menempel pada dinding tangki tunda. Buffle plate dibuat dari piringan Al dengan tebal 0,006 $\mathrm{m}$ dan diameter $1,40 \mathrm{~m}$. Buffle plate memiliki lubang-lubang berbentuk persegi dengan ukuran $0,06 \times 0,06 \mathrm{~m}$, jarak antar lubang $0,06 \mathrm{~m}$.

\section{Lokasi Penempatan Tangki Tunda}

Berdasarkan dari hasil penelitian di lapangan diketahui bahwa, keberadaan bulk shielding dengan sirkulasi air primernya yang 
sudah ada saat ini, perlu dipertahankan sebagai penyimpan sementara bahan bakar bekas dan peralatan nuklir lainnya yang terkontaminasi radiasi, sehingga tangki tunda dirancang untuk ditempatkan di luar bulk shielding dan tangki reaktor.

Jika bulk shielding yang sudah ada digunakan untuk penempatan tangki tunda hasil rancangan maka, perlu dibuatkan bulk shielding pengganti serta sistem sirkulasi air primernya. Hal ini tentu akan menimbulkan beban pekerjaan lain.

Tangki tunda hasil rancangan

ditempatkan di luar tangki reaktor, sehingga

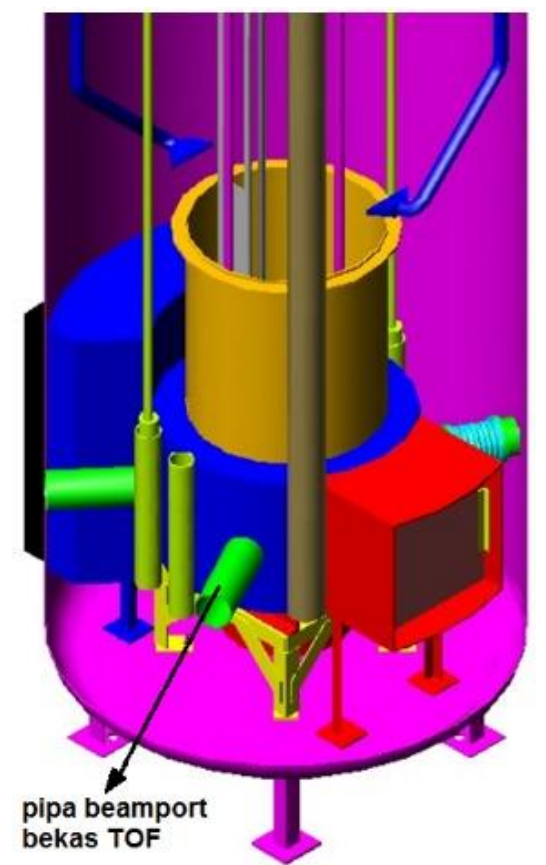

(a) air pendingin primer dari teras reaktor dialirkan ke tangki tunda melalui pipa beamport bekas TOF (time of flight) dengan bypass (Gambar 15). Posisi ujung pipa berkas TOF sebagai pipa masukan air pendingin primer dari teras reaktor ke tangki tunda hasil rancangan berada pada ketinggian $100 \mathrm{~cm}$ dari lantai gedung reaktor (Gambar 16). Adapun Lokasi penempatan tangki tunda ini adalah ruang bekas TOF di reaktor hall berukuran $200 \mathrm{~cm} \times 500 \mathrm{~cm}$ yang di sekelilingnya sudah terpasang shielding beton dengan ketebalan $50 \mathrm{~cm}$ (Gambar 17).

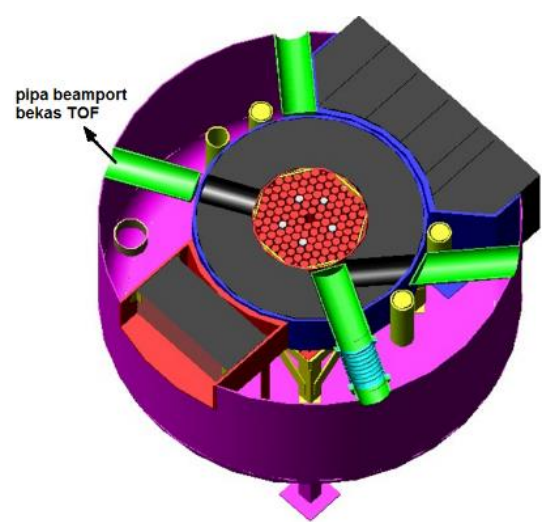

(b)

Gambar 15. (a) posisi pipa beamport bekas TOF di dalam tangki reaktor TRIGA 2000,dan (b) posisi pipa beamport dilihat dari pandangan tampak atas reaktor TRIGA 2000 


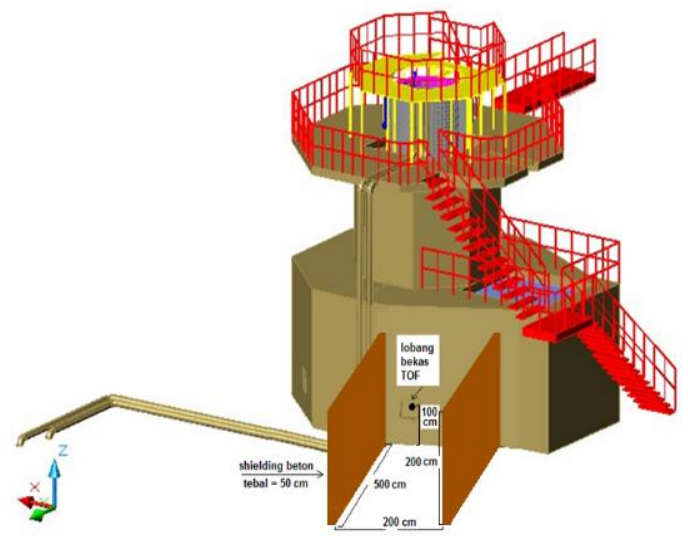

Gambar 16. Lokasi penempatan tangki tunda berdasarkan pandangan arah tenggara reaktor TRIGA 2000

\section{Rancangan Sistem Pemipaan}

Untuk menyederhanakan proses konversi, dilakukan minimalisasi penggantian komponen-komponen reaktor yang sudah ada, sehingga sistem pemipaan yang perlu diganti hanya sistem pemipaan dari samping kaki teras teras ke tangki tunda. Untuk mengalirkan air pendingin primer dari teras reaktor ke tangki tunda dirancang sistem pemipaan, dimulai dengan pipa keluar dari samping kaki teras dan dibelokkan ke atas hingga melebihi tinggi permukaan teras, kemudian dibelokkan ke bawah hingga berpotongan dengan pipa beamport bekas TOF yang menembus dinding tangki reaktor. Sistem pemipaan yang dibelokan ke atas hingga melebihi tinggi permukaan teras bertujuan untuk mempertahankan level air

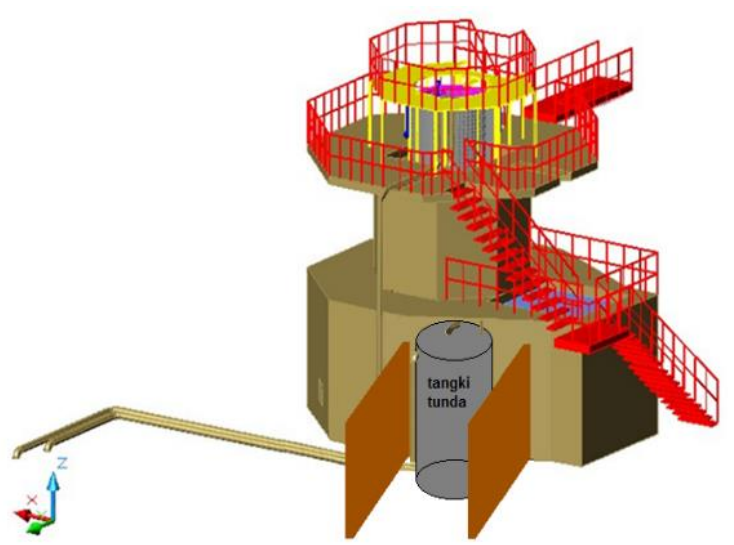

Gambar 17. Posisi penempatan tangki tunda di reaktor TRIGA Pelat

pendingin di dalam teras ketika terjadi kebocoran di tangki tunda atau di tempat lainnya. Sistem pemipaan ini tidak akan menghalangi proses loading dan unloading elemen bakar di teras reaktor, karena sistem pemipaan tersebut ditempatkan antara dinding luar reflektor dan dinding tangki.

Ujung pipa beamport bekas TOF yang menembus dinding tangki reaktor dihubungkan dengan pipa masukan tangki tunda. Selanjutnya pada pipa keluaran tangki tunda dihubungkan dengan pompa primer, alat penukar panas dan masukan ke teras menggunakan sistem pemipaan pendingin primer yang sudah tersedia sebelumnya. Visualisasi pemipaan ini dapat dilihat pada Gambar 18, 19, dan 20. 



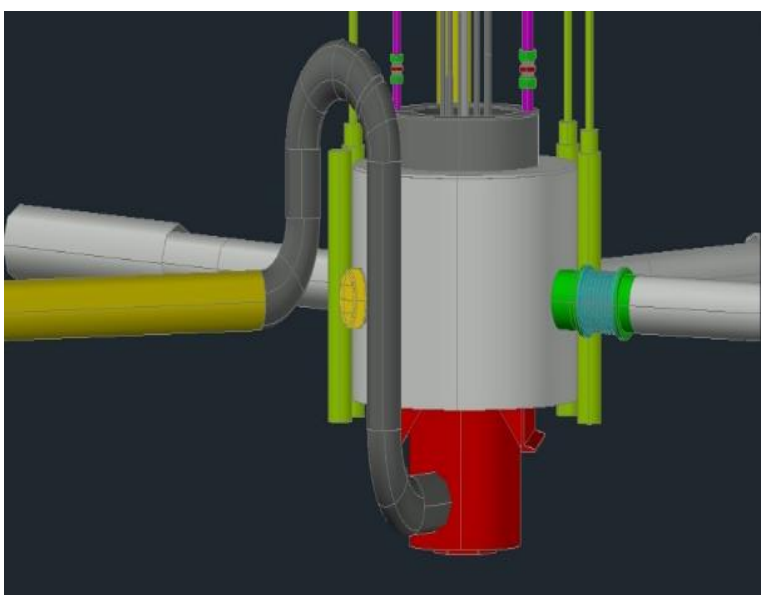

(a)

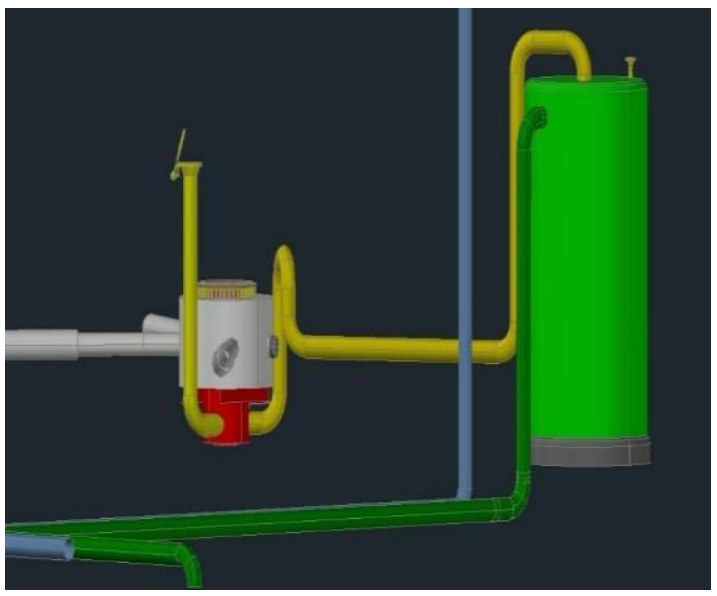

(b)

Gambar 18. (a) visualisasi rancangan sistem pemipaan primer dari samping kaki teras, dan (b) visualisasi rancangan sistem pemipaan primer dari kaki teras ke tangki tunda

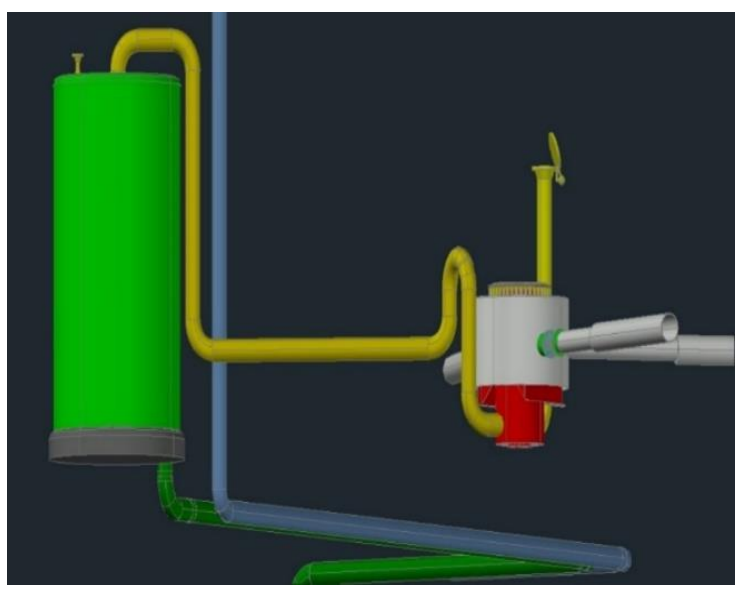

(a)

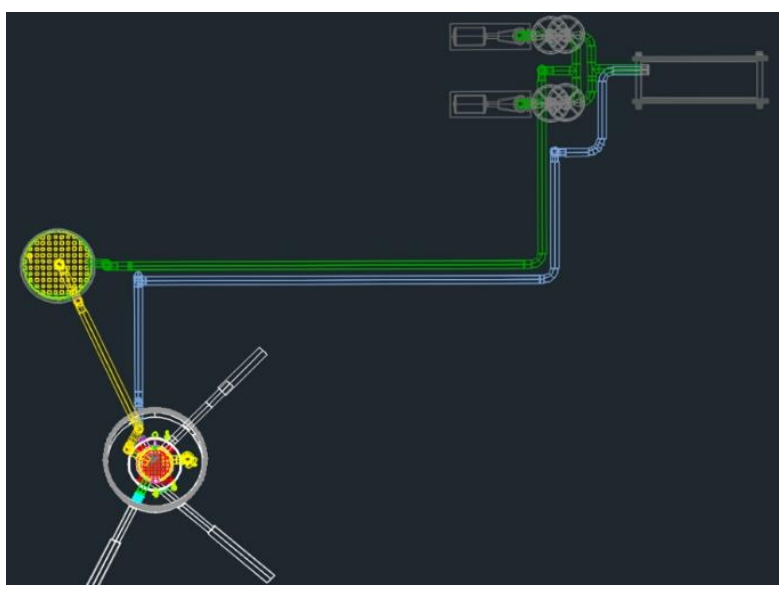

(b)

Gambar 19. (a) rancangan sistem pemipaan primer dari kaki teras ke tangki tunda, dan (b) rancangan sistem pemipaan primer pandangan atas 


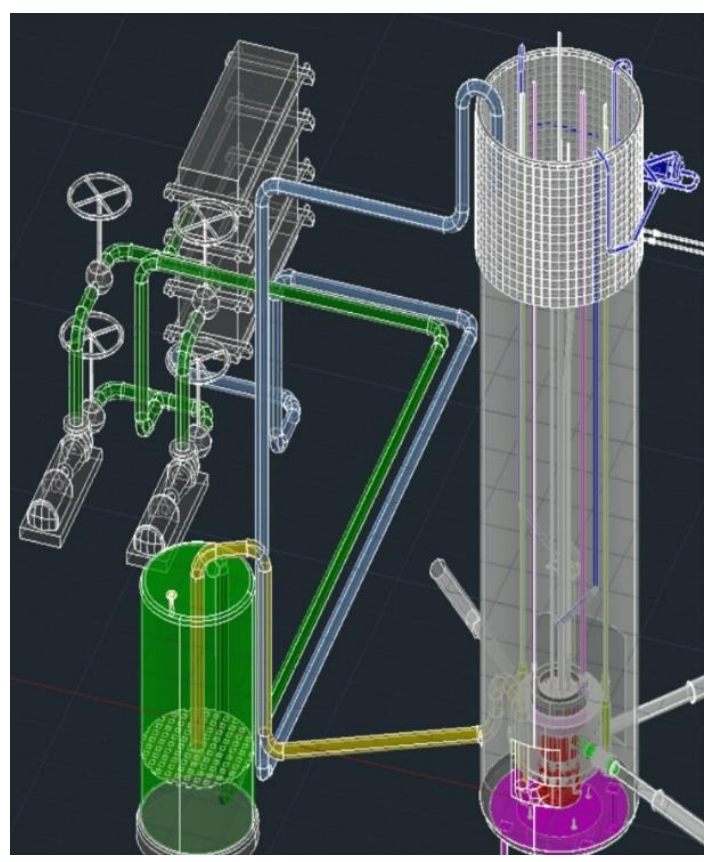

Gambar 20. Visualisasi keseluruhan sistem pemipaan pendingin primer reaktor TRIGA Pelat

\section{KESIMPULAN,}

Berdasarkan posisi penempatan pipa masukan dan pipa keluaran pada tangki tunda diketahui bahwa, model tangki tunda 3 buffle plate lebih menguntungkan. Dimana posisi pipa masukan dan pipa keluaran pada model tangki tunda 3 buffle plate membuat aliran air primer dari pipa masukan di dalam tangki tunda sebagai aliran jatuh bebas, sehingga lebih meringankan kerja pompa, dan mengurangi terjadinya pressure drop pada aliran di dalam tangki tunda.

\section{UCAPAN TERIMAKASIH}

Penulis mengucapkan terima kasih kepada PSTNT atas dukungan pada penelitian ini dengan mengalokasikan dana DIPA PSTNT BATAN tahun 2017, dan tim konversi reaktor atas kontribusinya dalam kegiatan penelitian ini.

\section{DAFTAR PUSTAKA}

1. Suwarno H. Development of TRIGA Fuel Fabrication by Powder Technique, Atom Indonesia 2014; 40(3):113 - 120.

2. G. Hampel. The Importance of TRIGA Reactors. on Behalf of the European TRIGA community. Johannes GutenbergUniversitat Mainz D-55099; 2010.

3. Van Den Berghe Sven, Leenaers Ann, Koonen Edgar and Sannen Leo. From High to Low Enriched Uranium Fuel in Research Reactors. Advances in Science and Technology 2010; 73:78-90.

4. Mandala AG. Simulasi Modifikasi Reaktor TRIGA 2000 Bandung Dengan Bahan Bakar Jenis Pelat. Proseding Seminar Nasional VI; 18 November 2010; Yogyakarta: STTN-BATAN;2010 
5. Mandala AG, Sihana, Harto WA, Termohidrolik usulan modifikasi reaktor nuklir TRIGA 2000 Bandung dengan bahan bakar jenis pelat. Prosiding Seminar Keselamatan Nuklir; 27 - 28 Juni 2011; Jakarta: BAPETEN;2011.

6. Kustiantini AS, Hastuti PE, Widodo S, Nazar R. Analisis Konveksi Alam Teras Reaktor TRIGA Berbahan Bakar Tipe Pelat Menggunakan Coolod-N2. Jurnal Teknologi Reaktor Nuklir TRI DASA MEGA 2015;17(2):67-78.

7. Subekti M, Isnaini D, Hastuti PE. Analisis Kecepatan Pendingin Dalam Elemen Bakar Tipe Plat Menggunakan Metode CFD Untuk Reaktor Riset RSG GAS, Jurnal Teknologi Reaktor Nuklir TRI DASA MEGA 2013;15(2):67-76.

8. Basuki P, Yazid PI, Suud Z. Desain Neutronik Konversi Elemen Bakar Tipe Pelat pada Teras TRIGA 2000 Bandung, Jurnal Sains dan Teknologi Nuklir Indonesia 2014;15(2):69-79.

9. Namgyung Jeong, Kyoung Seo, DaeYoung Chi, Yuhyeun Yoon. Estimation of Flow Residence Time in a Decay Tank for a Pool Type Research Reactor Using CFD, Nuclear Engineering and Design 2013; 255:162-168.

10.Gyuhong Roh, Seonghoon Kim, Yuhyeon Yoon. Design Evaluation of Decay Tank for a Pool-Type Research Reactor from the Required Minimum Flow Residence Time Point of View, Journal Science and Technology 2014; 51(90):1064-1072.
11.Seo K, Park YC, Chi D, Yoon J. Design of a decay tank for a pool type research reactor with a CFD model. The 14th International Topical Meeting on Nuclear Reactor Thermal Hydraulics; 25-30 September 2011;Toronto; 2011.

12.Gaurav Verma, Samiran Sengupta, Vijay K.Veluri, S. Mammen and S. Bhattacharya. Numerical study of fluid velocity distribution and residence time estimation for a delay tank of a nuclear research reactor. 42nd National Conference on Fluid Mechanics and Fluid Power (FMFP 2015), 2015 December 14-16, NIT K Surathkal; 2015. 

Rancangan Tangki Tunda Reaktor TRIGA Pelat Bandung

(Reinaldy Nazar) 